\title{
DUCH USTAWY O PRAWIE AUTORSKIM I PRAWACH POKREWNYCH - 20 LAT ULATNIANIA SIĘ
}

Erozja prawa jest procesem naturalnym - im dalej w czasie od jego uchwalenia, tym mniej prawników, beneficjentów, adresatów pamięta o jego celu i założeniach, tym szybciej jego duch jest pożerany przez język, doktrynę, praktykę, politykę. Ustawa o prawie autorskim i prawach pokrewnych to świetny przykład odstępowania w wielu miejscach, w miarę jej stosowania i nowelizowania, od ducha ustawy i celu zawartego w uzasadnieniu jej projektu z 1994 r. Gdy szukałem w miarę obiektywnego punktu odniesienia dla postawionej w tytule tezy, „Uzasadnienie projektu ustawy o prawie autorskim i prawach pokrewnych" z 1994 r. ${ }^{1}$ wydało mi się najwłaściwsze do dalszych rozważań nad ulatnianiem się ducha prawa autorskiego w minionym 20-leciu.

W życiu ustawy o prawie autorskim z 1994 r. ${ }^{2}$ możemy znaleźć dwa etapy: pierwszy, mniej więcej do 2000 r. - kiedy uważano, że nikt się na niej nie zna i że to całkiem nowa w polskim systemie prawa regulacja, drugi, trwający od 2000 r. do dnia dzisiejszego - gdy nagle wszyscy się na niej znaja!! W tym czasie duch ustawy znalazł dla siebie wiele szczelin. Najważniejsze z nich to: nowelizacje, w tym poziom implementacji dyrektyw i przepisów konwencyjnych, upadek techniki legislacyjnej, orzecznictwo, i to na wszystkich szczeblach orzekania sądowego, dalej doktryna prawnicza, a także działalność prawników praktyków, słabo wykształconych w zakresie ochrony własności intelektualnej. Dla nowelizowania ustawy i jej stosowania nie mniej ważne okazały się także: aktywność IV władzy - mediów - manipulacyjna, jednostronna, pomijająca wiedzę prawniczą i rzetelność dziennikarska, kłaniająca się reklamodawcom, oraz niski poziom świadomości prawnej społeczeństwa - zarówno użytkowników, jak i twórców kultury, a na końcu działalność polityków przemożnie przechylająca się ku rynkowemu postrzeganiu wszystkiego i zaspokajaniu populistycznych oczekiwań swoich wyborców.

Niepodważalnymi dotąd fundamentami prawa autorskiego były: prymat autora, jako podmiotu prawa autorskiego; akt rozpowszechniania dzieła, a nie zarobkowania na nim, jako istotne i wyłączne uprawnienie autora uruchamiające w razie jego naruszenia ochronę prawnoautorska; przewaga elementów moralnych, osobistych nad elementami majątkowymi; niematerialność przedmiotu ochrony i możliwość poddania go ochronie już tylko z tytułu zakomuni-

\footnotetext{
${ }^{1}$ Projekt ustawy o prawie autorskim i prawach pokrewnych, Druk sejmowy nr 86 z 6 listopada $1993 \mathrm{r}$.

${ }^{2}$ Ustawa z 4 lutego 1994 r. o prawie autorskim i prawach pokrewnych, t.jedn.: Dz. U. 2006, Nr 90, poz. 631 ze zm. (dalej jako: pr.aut.).
} 
kowania, a nie materializacji; wyłączność decydowania uprawnionych o wszelkich formach eksploatacji utworu. Te szczególne zasady ochrony twórczości powinny skłaniać do odrębnego regulowania praw autorskich i pokrewnych w całym systemie prawa polskiego, i to kompleksowo, co do wszelkich aspektów, w tym aspektów rynkowych i podatkowych.

Od kilku lat odstępstwo od tych zasad i ducha ustawy widoczne jest w swoistym uhandlowieniu prawa autorskiego, interpretacji przez pryzmat rynku i potrzeb użytkowników. Z tego powodu twórcy znaleźli się w sytuacji rodem z XVIII w. - przełamywania monopolu właścicieli środków przekazu, dostawców usług, gildii wydawniczych i producenckich, pośredników, a to przecież twórcom ustawa przyznaje prawa wyłączne i oni uruchamiaja uzyskiwanie korzyści przez wyżej wymienionych. Skutkiem tego sa zachowania społeczne, odbiorców twórczości, cofnięte do czasów rzymskich - istnieje to, co materialne, płacić trzeba tylko za to, co da się wziąć do ręki. Twórcy i organizacje ich reprezentujace zaczynają biegać, jak ongiś Albrecht Dürer, Marcin Luter, Pierre de Beaumarchais, od urzędu do urzędu, od króla do użytkownika, od posła do senatora, aby zrozumieli, że istnieje nie tylko odbiorca-wyborca, nie tylko rynek, a kultury narodowej nie da się kupić w Chinach czy Korei, jak smartfona i tabletu.

Skutkiem braku kompleksowej regulacji problematyki prawa autorskiego było w minionym okresie choćby błędne stosownie do prawa autorskiego i zbiorowego zarządu prawami norm wolnościowych prawa konkurencji. Decyzje Prezesa Urzędu Ochrony Konkurencji i Konsumentów ${ }^{3}$, a także sądu konkurencji ${ }^{4}$ odwołujące się do sektorowych przepisów prawa konkurencji bez uwzględnienia celów prawa autorskiego wręcz szkodziły rynkowi. Między innymi zmusiły organizacje do podwyższenia stawek wynagrodzeń dla użytkowników, wbrew interesowi rynku. To jeden z przypadków, w którym przepisy przesłoniły zarówno urzędowi, jak i sądowi faktyczne dobro rynku, dobro uprawnionych i użytkowników. Na szczęście wyciagnięto z tego wnioski i częściowo naprawiono sytuację, wprowadzając do pr.aut. przepisy o zawieraniu porozumień między organizacjami zbiorowego zarządzania $(\mathrm{OZZ})^{5}$, bez których nie jest możliwe tanie i komfortowe dla użytkowników licencjonowanie milionów utworów i dóbr pokrewnych.

Uzasadnienie projektu ustawy w pkt 1 wskazywało, że: „Uchylenie wiążących wzorców umów [...] stworzyło niebezpieczeństwo przewagi podmiotów profesjonalnie zajmujących się korzystaniem z twórczości i dysponujących znaczna przewagą organizacyjną i ekonomiczną. Nadaje to szczególne znaczenie funkcji ochronnej ustawy o prawie autorskim, mającej m.in. na celu wyrównanie ekonomicznej nierównowagi stron”6. I dalej: „Uwzględniona zo-

\footnotetext{
${ }^{3}$ Decyzja Prezesa UOKIK (DOK-6/2008 z 29 sierpnia 2008 r), www.decyzje.uokik.gov.pl/ dec_prez.nsf/0/EFA.

${ }^{4}$ Wyrok SO w Warszawie - Sądu Ochrony Konkurencji i Konsumentów z 8 lipca 2011 r., XVII AmA 23/09 (www.orzecznictwo.uokik.gov.pl) oraz wyrok SA w Warszawie z 1 marca 2012 r., VI A Ca 1179/11, Lex, nr 1167649.

${ }^{5}$ Art. $107^{1}$ pr.aut.

${ }^{6}$ Uzasadnienie Projektu ustawy o prawie autorskim i prawach pokrewnych, druk sejmowy nr 86 z 6 listopada 1993 r., pkt 1, s. 36 (dalej jako: Uzasadnienie).
} 
stała zasada, że ochrona autorska ma znaczenie nie tylko dla obrotu gospodarczego, ale także stanowi instrument stymulowania twórczości oraz stwarza podstawę do ochrony wartości kulturalnych (np. przed zniekształceniami lub przywłaszczeniami), chroni dziedzictwo kulturowe i ma poważne znaczenie w kształtowaniu kultury społeczeństwa"7. Jak maja się do tego usiłowania użytkowników i administracji państwowej ${ }^{8}$ wprowadzenia twórczości w obszar „informacji publicznej” dostępnej, jak dokumenty i inne materiały urzędowe, próby wyłączenia przez użytkowników prawa do decydowania przez twórcę o rozpowszechnianiu opracowań, próby zmiany art. 79 ustawy (podwójnego $\mathrm{i}$ potrójnego wynagrodzenia $\mathrm{w}$ przypadku zawinionego naruszenia autorskich praw majatkowych). W tej sprawie Uzasadnienie rozstrzyga istotność tego przepisu: „wyposażenie autora i jego następcy prawnego w to roszczenie (tj. podwójnego wynagrodzenia) ułatwi dochodzenie odpowiedzialności i usunie niebezpieczeństwo, że naruszajacy znajdzie się w korzystniejszej sytuacji niż osoba legalnie wykorzystująca utwór. W obecnej chwili najczęściej odpowiedzialność za naruszenie autorskich praw majątkowych sprowadza się do wypłacenia, dodatkowo ze znacznym opóźnieniem, wynagrodzenia, którego autor mógłby oczekiwać w wypadku legalnej eksploatacji, mimo że wykorzystanie nastapiło bez zgody uprawnionego albo wbrew jego woli. Taki stan rzeczy podważa sens zawierania umowy"9. Mam nadzieję, że Trybunał Konstytucyjny, rozpatrując skarge $e^{10} \mathrm{w}$ tej sprawie, weźmie pod uwagę istotność przepisu art. 79 dla ochrony twórczości i równowagi stron użytkownik - twórca.

Rozszczelnieniu funkcji ochronnej ustawy służą także próby zmiany przepisów karnych pod pretekstem niejasności treści prawa autorskiego, niepewności prawnej użytkownika, zwłaszcza fizycznego odbiorcy, braku określoności czynu zabronionego ${ }^{11}$. Szermuje się szeroko argumentem, że odbiorca nie wie, gdy pobiera coś z Internetu, czy robi to legalnie, czy nielegalnie. W Polsce dzieje się to w sytuacji, gdy cały świat zaostrza przepisy karne chroniące własność intelektualna. Uzasadnienie w pkt 19 podaje: „istotnym elementem [...] zabezpieczającym system ochrony twórców, producentów, organizacji radiowych i telewizyjnych są rozbudowane przepisy karne. Mają one szczególne znaczenie wobec dotkliwego zjawiska piractwa, występującego ze szczególnym natę-

\footnotetext{
${ }^{7}$ Ibidem, s. 37.

8 „Projektu założeń projektu ustawy o otwartych zasobach publicznych” z 28 grudnia 2012 r., http://mac.bip.gov.pl/projekty-aktow-prawnych/projekt-zalozen-projektu-ustawy-o-otwartych-zasobach-publicznych.html z datą 28 grudnia 2012 r. Ponadto projekt założeń do ustawy o otwartych zasobach publicznych opublikowano na stronach Rządowego Centrum Legislacji pod numerem ZA2. „Projekt założeń projektu ustawy o ponownym wykorzystaniu informacji sektora publicznego" http://mac.bip.gov.pl/projekty-aktow-prawnych/projekt-zalozen-projektu-ustawy-o-ponownym-wykorzystywaniu-informacji-sektora-publicznego.html z datą 23 maja 2014 r. Ponadto projekt założeń do ustawy re-use opublikowano na stronach Rządowego Centrum Legislacji pod numerem ZC37.

${ }^{9}$ Pkt 13, s. 41 Uzasadnienia.

${ }^{10}$ Skarga konstytucyjna (art. 79 PrAut) z wniosku UPC Polska Sp. z o.o. w Warszawie, SK 32/14 (trybunal.gov.pl/s/sk-3214).

${ }^{11}$ Wniosek Rzecznika Praw Obywatelskich o stwierdzenie, że art. 115 ust. 3 PrAut jest niezgodny z art. 42 ust. 1 Konstytucji, K 15/13. Trybunał wyrokiem z 17 lutego 2015 r. orzekł o zgodności przepisu z Konstytucja.
} 
żeniem w obrocie prawami autorskimi i pokrewnymi"12. Od roku 1994 do dzisiaj nic się nie zmieniło, a raczej pogorszyło - Polska jest w czołówce państw, w których dokonuje się największej na świecie liczby nielegalnych pobrań i udostępnień filmów fabularnych ${ }^{13}$. Piractwo muzyczne obok nielegalnego powielania nośników znalazło sprzymierzeńca w technologii cyfrowej i elektronicznej wymianie plików. I choć nie można powiedzieć, że przepisy karne pr.aut. są martwe, to sądy stosują je łagodnie, zasądzając głównie grzywny, i to niewysokie, a wyrok bez zawieszenia kary pozbawienia wolności, także przy przestępstwach z art. 116 ust. 3, art. 117 ust. 2 czy art. 118 ustawy $^{14}-$ jak mi wiadomo - w minionym 20-leciu nie został nigdy orzeczony. Niechęć do stosowania tych przepisów przez organy ścigania widoczna jest szczególnie w ilości zażaleń na postanowienia prokuratorów odmawiające wszczęcia dochodzenia lub umarzające już wszczęte ${ }^{15}$. Prześledzić to można w statystykach Ministerstwa Sprawiedliwości i międzyresortowego Zespołu do spraw Przeciwdziałania Naruszeniom Prawa Autorskiego i Praw Pokrewnych ${ }^{16}$.

A oto kilka innych przykładów ulatniania się ducha ustawy wielokrotnie o fundamentalnych skutkach dla ochrony twórczości i sytuacji majątkowej i osobistej polskich twórców. W punkcie 8 Uzasadnienia czytamy: „novum stanowi przywrócenie tzw. droit de suite. [...] W ten sposób twórcom zostaje zapewniony niezbywalny udział w zwyżce wartości dzieł plastycznych oraz zostanie stworzona (wobec zastrzeżonego w konwencji berneńskiej warunku wzajemności) podstawa do inkasowania tych opłat z zagranicy" ${ }^{17} \mathrm{i}$ dalej w pkt 14: ustanawia się „szereg uprawnień dla ozz [...] do dochodzenia opłat od [...] droit de suite" 18 . Najpierw minister kultury w 1995 r. powierza prawo do inkasa organizacjom nieprzygotowanym do zbiorowego zarządu na tym polu, aby później ustawodawca usunął przepis ustawy i wyłączył obowiązkowe po-

12 Pkt 19, s. 43 Uzasadnienia.

${ }^{13}$ Np. w nielegalnych pobraniach popularnego serialu House of Cards w sezonie 2012/13 Polacy byli na drugim miejscu na świecie po Amerykanach (D. Libicki, Cyfrowy Polsat).

${ }_{14}$ Przestępstwa z ww. artykułów są przestępstwami umyślnymi, kwalifikowanymi, popełnianymi w warunkach stałego źródła dochodów sprawcy, organizowania lub kierowania działalnością przestępczą lub w celu osiagnięcia korzyści majątkowych, wszystkie zagrożone samoistnymi karami pozbawienia wolności do lat 2 , do lat 3 lub 5.

15 Stowarzyszenie Autorów ZAiKS w latach 2009-2013 złożyło 125 zażaleń na postanowienia prokuratorskie odmawiające wszczęcia dochodzenia lub je umarzające. Podstawą tych postanowień były przeważnie: 1) znikoma szkodliwość czynu (art. 17 § 1 pkt 3 k.p.k.) - powoływanie się na małą szkodę, zrealizowanie obowiązku naprawienia szkody, krótki okres bezprawnej działalności i niestety rodzaj chronionego dobra (własność intelektualna postrzegana jako dobro mniej chronione niż własność materialna), 2) brak cech przestępstwa (art. $17 \S 1$ pkt 2 k.p.k.) - z reguły powoływanie się na dozwolony użytek pomimo niespełnienia jego przesłanek; także sporadycznie powoływanie się na wcześniej zawartą umowę z inną OZZ z kręgu praw pokrewnych; powoływanie się na brak umyślności w działaniu sprawcy mimo penalizowania takiego zachowania w art. 116 ust. 4 pr.aut., 3) brak danych, dostatecznie uzasadniajaccych podejrzenie popełnienia przestępstwa (art. $17 \S 1$ pkt 1 k.p.k.) - z reguły brak identyfikacji konkretnych autorów oraz utworów, pomimo dowodu lub nawet przyznania się przez podejrzanego do długotrwałego korzystania $\mathrm{z}$ utworów.

16 Zob. www.prawoautorskie.gov.pl.

17 Pkt 8, s. 39 Uzasadnienia.

18 Pkt 14, s. 42 Uzasadnienia. 
średnictwo OZZ-etu ${ }^{19}$, i faktycznie uniemożliwił inkaso na rzecz polskich plastyków, fotografików, literatów i kompozytorów należnych im wynagrodzeń, powszechnie na świecie inkasowanych.

Punkt 9 Uzasadnienia brzmi: „novum stanowi także wprowadzenie wpłat od cen sprzedaży tzw. czystych nośników obrazu i dźwięku oraz aparatury służącej do reprodukcji obrazu i dźwięku. Wzrastająca liczba nagrań dokonywanych w ramach użytku prywatnego, stanowi poważne zagrożenie dla interesów twórców, artystów wykonawców i producentów fono i wideogramów. Opłaty te, przyjmowane w nowoczesnych ustawodawstwach i traktowane w nich jako wynagrodzenie autorskie z tytułu reprodukowania utworów, będą ustalane przez Ministra Kultury i Sztuki w porozumieniu z organizacjami ochrony twórców, artystów wykonawców oraz producentów [...] itd." ${ }^{20}$. Brak informacji o tym, aby którykolwiek z ministrów w czasie obowiązywania ustawy samodzielnie zainicjował objęcie tą opłatą nowych urządzeń i nośników w normalnym trybie art. 20 ust. 5 pr.aut. Od 2 lat odbywa się bezpardonowe zwalczanie tej opłaty przez producentów i importerów urządzeń i nośników. Po 20 latach obowiązywania przepisu - upolitycznienie opłaty reprograficznej (przewodniczący sejmowej Komisji Innowacyjności i Nowych Technologii ${ }^{21}$ nazywa ja podatkiem, tak zreszta jak i prasa, zajmuja się nią ministrowie gospodarki, administracji i cyfryzacji, senatorowie) jest wzorcowym przykładem jednoczesnego wystapienia wszystkich wymienionych przeze mnie na początku szczelin ustawy. Podejmowana w tym zakresie dyskusja, zwłaszcza przez organy państwa, jest zaskakujaca w obliczu orzeczenia Trybunału Konstytucyjnego z 2011 r., który przesądził słuszność pobierania tej opłaty przez OZZ-ety i jej cywilnoprawny charakter ${ }^{22}$. Przepis regulujący tzw. opłatę reprograficzną powinien odwoływać się uniwersalnie do każdego urządzenia pojawiającego się na rynku w wyniku rozwoju technologicznego i spełniającego ustawowe kryteria, a nie uzależniać ich katalog od refleksu, wiedzy czy widzimisię urzędnika państwowego, dając asumpt do politycznych nacisków, kampanii strachu podwyżki cen serwowanej przez producentów, a w skutkach utraty w Polsce od co najmniej 4 lat wynagrodzeń dla ustawowo uprawnionych. Widać to wyraźnie w inkasie per capita z tego tytułu za rok 2012 w poszczególnych krajach Unii Europejskiej: Francja - 2,65 euro, Belgia - 2,14 euro, Węgry - 1,22 euro, Włochy - 1,18 euro, Litwa - 0,66 euro, Dania - 0,79 euro, Austria - 0,78 euro, Czechy - 0,31 euro, Polska - 0,04 euro ${ }^{23}$. Wiele z tych krajów ludnościowo jest 5-krotnie mniejszych od Polski.

W pkt 7 Uzasadnienia czytamy: „projekt przestrzega zasady równości sektorów, swobody prowadzenia działalności gospodarczej, z zachowaniem minimum reglamentacji zmierzającej do ochrony strony słabszej. [...] Wśród

19 Ustawa z 23 marca 2006 r. o zmianie ustawy o prawie autorskim i prawach pokrewnych, Dz. U. 2006, Nr 66, poz. 474.

${ }^{20}$ Pkt 9, s. 40 Uzasadnienia.

${ }_{21}$ Posiedzenie 133 komisji, wspólne z Komisją Kultury i Środków Przekazu www.sejm.gov. $\mathrm{pl} / \mathrm{sejm} 7 . \mathrm{nsf} / \mathrm{P}$.

22 Orzeczenie Trybunału Konstytucyjnego z 11 października 2011 r., P 18/09, OTK-A 2011, nr 8, poz. 81 .

${ }^{23}$ International Survey on Private Copying 2013. 
nielicznych przepisów ochronnych o charakterze bezwzględnym wymienić zwłaszcza należy zakaz zbywania praw do wszystkich utworów w przyszłości, rozporządzania sposobami eksploatacji nieznanymi w momencie zawierania umowy oraz obowiązek wyraźnego wymieniania pól eksploatacji, których dotyczy zawarte w umowie rozporządzenie" ${ }^{24}$. Każdy z tych zakazów został wielokrotnie złamany $\mathrm{w}$ umowach rozporządzających prawami zawieranych przez autorów z wydawcami, nadawcami, producentami, ale co dziwne, możliwość ich obchodzenia niejednokrotnie potwierdza doktryna prawna i orzekaja sądy, odwołując się do tych samych przepisów, co projekt ustawy.

Podobny sposób postępowania z ustawą o prawie autorskim znaleźć możemy przy interpretacji domniemań w ustawie, zwłaszcza zawartych w art. 105 i 70 pr.aut. W przypadku domniemania zarządu OZZ-etu sądom wystarczało istnienie dwóch uprawnionych na tym samym polu organizacji, bez względu na to, czy ta druga rościła sobie prawo do tego samego utworu, aby kwestionować ich legitymację $e^{25}$, wbrew ustalonemu wcześniej orzecznictwu ${ }^{26}$. Z podobnymi problemami spotykały się OZZ-ety przy wykonywaniu roszczenia informacyjnego z art. 105 ust. 2 pr.aut. i dopiero sądy apelacyjne i Sąd Najwyższy rozstrzygały o samodzielności tego roszczenia ${ }^{27}$. Sądy interpretowały też przeciw uprawnionym domniemanie $\mathrm{z}$ art. 70, odwracając zobowiązanego do obalenia domniemania ${ }^{28}$ wbrew wyraźnemu zapisowi ustawy i intencji ustawodawcy ${ }^{29}$. Choć trudno polemizować z orzeczeniami Trybunału Konstytucyjnego ${ }^{30}$, wydaje się, że w przypadku oceny art. 70 ust. 2 pr.aut. wypowiedział się wbrew przemyślanemu zamiarowi początkowemu ustawodawcy - wynagrodzenia głównych autorów i aktorów filmu wpływających na jego popularność, a w konsekwencji na zyski producenta i całego przemysłu filmowego. Orzeczenie to zapoczątkowało dalszy ciąg pomyłek i błędów w nowelizacji przepisu art. 70 ust. $2^{1}$ pr.aut. i orzeczeń Sądu Najwyższego, a nawet jego uchwał 7 sędziów ${ }^{31}$. Za tym poszło szereg wątpliwych orzeczeń sądów okręgowych i apelacyjnych w sprawach o zapłatę wynagrodzeń autorskich z tytułu eksploatacji utworów audiowizualnych. Wprowadzenie przez nowelizację ${ }^{32}$ do przepisu pojęcia „współautorstwo” w rozumieniu art. 9 pr.aut., wbrew zamiarowi Trybunału, spowodowało totalne zamieszanie w skutecznym jego stosowaniu i interpretacji, a co za tym idzie pogorszenie egzekucji wynagrodzeń dla uprawnionych. Podobny skutek odniosło użycie w przepisie pojęcia ,inne środki publicznego udostępniania

\footnotetext{
24 Pkt 7, s. 39 Uzasadnienia.

25 Np. wyrok SA w Warszawie z 8 października 2013 r., IACa 287/13, niepubl.

${ }^{26}$ Np. wyrok SN z 27 czerwca 2013 r., I CSK 617/12; wyrok SA w Warszawie z 9 lutego 2007 r., VI ACa 931/06; wyrok SA w Warszawie z 3 czerwca 2009 r., I ACa 248/09, niepubl.

27 Np. uchwała SN - Izba Cywilna z 17 września 2009 r., III CZP 57/2009 r.; wyrok SN z 27 września 2013 r., I CSK 696/12.

${ }^{28}$ Wyrok SA w Warszawie z 7 maja 2014 r., IAca 1663/13, niepubl.

29 Sąd Najwyższy wyrokiem z 17 września 2014 r., I CSK 621/13, Lex, nr 1537547 zmienił błędną linię orzeczniczą w tym zakresie, wskazując na producenta, jako zobowiązanego do udowodnienia posiadania prawa do eksploatacji utworu wkładowego w utworze audiowizualnym.

${ }^{30}$ Wyrok TK z 24 maja 2006 r., Dz. U. Nr 94, poz. 658.

31 Uchwała SN 7 sędziów z 25 listopada 2008 r., III CZP 57/08, OSNC 2009, nr 5, poz. 64.

32 Ustawa z 7 września 2007 r., Dz. U. Nr 181, poz. 1293.
} 
utworów”, którego od siedmiu lat nie potrafi opisać doktryna prawna, a sądy skupiły się wyłącznie na literalnej wykładni przepisów o nadaniach, reemisji i dostępie cyfrowym, mam wrażenie, że wbrew intencji Trybunału, wbrew duchowi ustawy i z narażeniem jej i konstytucyjnych fundamentalnych zasad ochrony słabszego i proporcjonalności.

Do takich wprowadzonych nowelizacją ${ }^{33}$ kuriozów ustawodawczych uniemożliwiających sensowne stosowanie przepisu należy także „kwota ogólnego obciążenia podmiotów korzystających z utworów lub przedmiotów praw pokrewnych na rzecz wszystkich organizacji zbiorowego zarządzania z tytułu korzystania z praw autorskich i pokrewnych na danym polu eksploatacji”, narzucona, jako jedno z kryteriów, które brać musi pod uwagę Komisja Prawa Autorskiego (KPA) przy orzekaniu zatwierdzajacym tabele wynagrodzeń twórczych zgłaszanych przez OZZ-ety. To tylko jedna z przyczyn blokujących prawidłowe uchwalanie tabel wynagrodzeń autorskich, ze szkodą dla tysięcy autorów i niepewności użytkowników. Zwlekanie z nowelizacją przepisów o zatwierdzaniu tabel wynagrodzeń (rozdz. 12, oddział 2 pr.aut.), postulowana już przez pierwszy skład KPA po zmianie przepisów, osłabia cały system zarządzania prawami i działa na szkodę uprawnionych oraz użytkowników.

Z działalnością OZZ-etów związane są również podsycane przez użytkowników zarzuty o braku ich transparentności. Oczywiście podstawą tych zarzutów jest rosnąca skuteczność większości z tych organizacji w egzekwowaniu wynagrodzeń z tytułu praw autorskich i pokrewnych - już nie tylko ZAiKS-u obecnego na rynku od 1918 r., ale także SFP, ZASP-u, STOART-u, SAWP-u, ZPAV-u, KOPIPOL-u, REPROPOL-u, COPYRIGHT - Polska Książka, które uzyskały zezwolenia ministra kultury na zbiorowy zarząd w 1995 r. Organizacje te $\mathrm{z}$ mocy ustawy działajace $\mathrm{w}$ formie stowarzyszeń podlegają nadzorowi ministra kultury i dodatkowo od 2010 r. ${ }^{35}$ zobowiązane sa do prowadzenia ksiag rachunkowych i sporządzania sprawozdania finansowego według zasad ustawy o rachunkowości i poddawania go corocznemu badaniu przez zewnętrznego biegłego rewidenta. Przekazują także corocznie szczegółowe sprawozdanie z działalności ministrowi kultury, według wzoru określonego w rozporządzeniu ministra ${ }^{36}$. Sprawozdania te i wyniki badania rewidentów są publikowane na stronach internetowych Ministra Kultury i Dziedzictwa Narodowego oraz tych organizacji. Niektóre z nich, np. ZAiKS, publikują dodatkowo na swoich stronach $^{37}$ i w biuletynach obszerne wyjaśnienia i komentarze związane z interpretacją sprawozdań, aby umożliwić zrozumienie ich treści przez własnych członków i wszystkich zainteresowanych. Trzeba przy tym pamiętać, że są to

${ }^{33}$ Ustawa z 8 lipca 2010 r., Dz. U. Nr 152, poz. 1016.

${ }^{34}$ Art. $110^{13}$ ust. 5 pkt 2 pr.aut.

35 Ustawa z 8 lipca 2010 r. (Dz. U. Nr 152, poz. 1016) dodała art. 104 ust. $3^{1}$ - $3^{5}$ pr.aut.

${ }^{36}$ Rozporządzenie Ministra Kultury i Dziedzictwa Narodowego z 17 lipca 2014 r. w sprawie szczegółowego zakresu rocznego sprawozdania z działalności organizacji zbiorowego zarządzania prawami autorskimi lub prawami pokrewnymi, Dz. U. z 25 lipca 2014 r. Treść sprawozdań za lata 2011-2013 regulowało rozporządzenie Ministra Kultury i Dziedzictwa Narodowego z 18 kwietnia 2011 r. w sprawie szczegółowego zakresu rocznego sprawozdania z działalności organizacji zbiorowego zarządzania prawami autorskimi lub prawami pokrewnymi, Dz. U. 2011, Nr 88, poz. 497.

37 Zob. www.zaiks.org.pl, Sprawozdania. Wyjaśnienia i komentarze. 
podmioty prywatne, nienależące do sektora finansów publicznych. Przy tym wyjątkowym, jak dla podmiotów prywatnych i do tego działających non profit, zakresie sprawozdawczości i jej jawności są to organizacje o rozbudowanej kontroli wewnętrznej (komisje rewizyjne, rady nadzorcze, rady administracyjne, sądy koleżeńskie) oraz zarządzane przez organy (zarządy, prezydia) wybierane w demokratycznych wyborach, przeważnie przez zjazdy wszystkich członków lub uprawnionych albo ich delegatów. Większość z tych organizacji, wobec wykonywania zarządu także na rzecz zagranicznych twórców i uprawnionych, poddana jest rygorom ciał międzynarodowych. Na przykład ZAiKS ${ }^{38}$ i SFP, jako członkowie Międzynarodowej Konfederacji Związków Autorów i Kompozytorów CISAC z siedzibą w Paryżu, zobowiązane są do stosowania tzw. Zasad zawodowych w zbiorowym zarządzie i podlegają okresowej kontroli CISAC-u, a także kontroli zagranicznych OZZ-etów. Publikuja także sprawozdania w mediach Konfederacji. Dodatkowo stawki wynagrodzeń stosowane przez OZZ-ety na masowych polach eksploatacji ${ }^{39}$ muszą zostać zatwierdzone przez Komisję Prawa Autorskiego. Który z przedsiębiorców-użytkowników podlega tak rozbudowanej kontroli i jest tak transparentny? Poza tym, jak wszystkie podmioty działające w Polsce, OZZ-ety podlegają kontroli organów podatkowych, ZUS-u, inspekcji pracy, ochrony konkurencji, celnej itd.

Akt rozpowszechnienia utworu $\mathrm{w}$ wielu propozycjach nowelizacyjnych zgłaszanych przez różne podmioty jest podważany i próbuje się go zastapić pojęciem „komercyjność”, jako początku zobowiązań majątkowych na rzecz uprawnionych. Oczekiwanie tylko komercyjności - rozumianej jako przychód lub zysk po stronie korzystajacego z utworów - dla przyznania autorowi wynagrodzenia eliminuje tysiące twórców, artystów wykonawców, producentów z otrzymania należnego wynagrodzenia, gdy inny cel będzie przyświecał użytkownikowi i inna niż majątkowa perspektywa korzyści.

Brak znajomości ustawy przez wymiar sprawiedliwości przejawia się m.in. w naruszaniu terminów wprowadzonych przez ustawę, a szczególnie nagminnie 3-dniowego terminu, w którym sąd właściwy do rozpoznania sprawy o naruszenia autorskich praw majątkowych winien rozpatrzyć wniosek mającego interes prawny o zabezpieczenie dowodów i zobowiązanie do udzielenia informacji lub udostępnienia dokumentacji mających znaczenie dla dochodzenia roszczeń z tego tytułu ${ }^{40}$. Istotność szybkiego działania, wobec ulotności dowodów, konieczna przy ustalaniu skali naruszenia dobra niematerialnego nie jest przez sądy należycie dostrzegana.

Problemy z techniką legislacyjną widać na przykładzie wprowadzanych w życie nowelizacją z 2004 r. ${ }^{41}$ przepisów o dozwolonym użytku chronionych utworów stanowiących głównie implementację dyrektywy o społeczeństwie

\footnotetext{
${ }^{38}$ Stowarzyszenie Autorów ZAiKS ma zawartych 126 umów o wzajemnej reprezentacji z zagranicznymi OZZ-etami.

${ }^{39}$ Art. $110^{12}$ ust. 2 pr.aut. Obowiązek zatwierdzenia tabel dotyczy nadań, reemisji, odtworzenia, wynagrodzeń z tytułu eksploatacji utworu audiowizualnego. Brak zatwierdzenia tabeli w tym zakresie może być powodem do cofnięcia zezwolenia na zbiorowy zarząd, zgodnie z art. 104 ust. 5 pkt 3 pr.aut.

${ }_{40}$ Art. 80 pr.aut.

${ }^{41}$ Ustawa z 20 kwietnia 2004 r., Dz. U. Nr 96, poz. 959.
} 
informacyjnym ${ }^{42}$. Konieczność stosowania skomplikowanych metod interpretacyjnych, aby dotrzeć do sensu przepisu, zobrazować można na tle art. $33^{1}$ pr.aut. ${ }^{43}$, który skierowany jest do niekomercyjnych producentów egzemplarzy utworów dla osób niepełnosprawnych. Właściwa interpretacja tego przepisu możliwa jest dopiero po zapoznaniu się z pkt 43 preambuły dyrektywy w sprawie harmonizacji niektórych aspektów praw autorskich i praw pokrewnych $\mathrm{w}$ społeczeństwie informacyjnym ${ }^{44}$. Zwykły użytkownik praktycznie pozbawiony jest możliwości właściwego zastosowania przepisu - przeważnie sądzi, że dotyczy on korzystania z utworów w ramach terapii i rekonwalescencji niepełnosprawnych. W obliczu przygotowywanej szerokiej nowelizacji prawa autorskiego obejmującej dozwolony użytek, dzieła osierocone, wynagrodzenia za wypożyczenia biblioteczne pozostaje nadzieja, że ustawodawca wyciagną wnioski z dotychczasowego stosowania ustawy i nie popełni poprzednich błędów.

Wypowiedzenie się na temat postawiony autorowi w tytule artykułu musiało prowadzić do rozwiązania dylematu, czy zajmować się szczegółowo jednym wybranym problemem ustawy w jej 20-letnim przekroju, czy oceniać ja w całości, akceptując daleko posunięta ogólność i uproszczenia. Postawiłem na niepogłębiona analizę stosowania i nowelizowania ustawy na wybranych przykładach w celu zobrazowania różnych rodzajowo i gatunkowo jej ułomności i niedoskonałości, w konfrontacji z pierwotnym jej projektem i jego uzasadnieniem. Świadomie też nie odwołuję się w tekście do poglądów doktryny prawnej, a jedynie orzecznictwa, realizując może subiektywnie, ale jednak zadany temat.

Krzysztof Lewandowski

Dyrektor Generalny Stowarzyszenia Autorów ZAIKS

THE SPIRIT OF COPYRIGHT ACT: 20 YEARS OF DILUTION

Sum mary

In the paper, numerous instances and reasons for the decomposition of the Act on Copyright and Related Rights in the recent two decades have been identified, and the following are mentioned with reference to the fundamental principles of the author's rights: incorrect amendments, wrong implementations of the international regulations, imperfect functioning of the juridical doctrine and practice, wrong judicial decisions at all levels, as well as ignorance of law among creators and users, overwhelming influence on the legislation process on the media and various lobby groups, and politicians' extra-parliamentary interference in the application of the Act. The

${ }_{42}$ Dyrektywa Parlamentu Europejskiego i Rady z 22 maja 2001 r., Dz. Urz. UE L 167 z 22 czerwca 2001 r., s. 10 (dalej jako: dyrektywa InfoSoc).

${ }^{43}$ Art. $33^{1}$ pr.aut.: „Wolno korzystać z już rozpowszechnionych utworów dla dobra osób niepełnosprawnych, jeżeli to korzystanie odnosi się bezpośrednio do ich upośledzenia, nie ma zarobkowego charakteru i jest podejmowane w rozmiarze wynikającym z natury upośledzenia”.

${ }^{44}$ Pkt 43 preambuły dyrektywy InfoSoc: „w każdym przypadku istotne jest, aby państwa członkowskie przyjęły wszystkie konieczne środki w celu wspierania dostępu do utworów przez osoby niepełnosprawne, które mają utrudnione samodzielne korzystanie z utworów, biorąc pod uwagę dostępne formaty". 
merchandising of the Act and the perception of author's rights from the perspective of clients' needs and users' commercial purposes is also indicated, showing that the author's moral rights and unique creative works are pushed into the background. The necessity of a comprehensive regulation pertaining to the transfer of copyright and related rights within one act has been postulated and an example of a nonsensical application of fair competition rules to the collective management of author's rights is given. Dilution of copyright is also analysed on the basis of the explanatory memorandum to the Act of 1994 on Copyright and Related Rights which underlined its adoption. In this scope, a reference is made to the departure from the correct regulation of the droit de suite, the audiovisual work and the author's royalties related thereto, the regulations on collective management, the contra legem interpretation of the presumption of law (and among other things CMOs' authorizations and the acquisition of economic rights to the audiovisual work), the infringement of mandatory rules applicable to the act within the transfer of the author's economic rights, and misapplication of the provisions related to the reprography levies. The examples of the provisions implemented by the amendments to the Act illustrate the failure of the legislative technique and the necessary application of convoluted interpretation methods to reach the meaning of Article $33^{1}$ and subsequent articles. Disrespect to the Act is also confirmed by the fact that Polish courts do not apply statutory terms and conditions (e.g. Article 80 of the Copyright Act). Many adverse effects of the Act's application are caused by the doctrine which does not provide for any interpretation of numerous legal terms and institutions (e.g. the 'total amount of charges' in Article $110^{13}$ section 5 point 2; 'other means of public presentation' in Article 70 section $2^{1}$ point 3 of the Copyright Act). The proposed amendments to the Act, which depart even further from its spirit and impede adequate protection of the rights of authors, performers and the rights holders of related rights are also analysed. 